\title{
Innovations developed within supply chains hinder territorial ecological transition: the case of a watershed in Martinique
}

\author{
Pauline Della Rossa ${ }^{1,2}$ (1) Marianne Le Bail ${ }^{3}$. Charles Mottes ${ }^{1,2} \cdot$ Magalie Jannoyer $^{2,4} \cdot$ Philippe Cattan $^{2,5}$
}

Accepted: 30 January 2020 / Published online: 24 February 2020

(C) INRAE and Springer-Verlag France SAS, part of Springer Nature 2020

\begin{abstract}
Some chemical herbicides used by farmers in Martinique contaminate rivers. Agroecological innovations exist, some of which are known by the stakeholders but are not systematically used at the scale of the watersheds concerned. Our hypothesis is that the sociotechnical agricultural supply chain system built over the last 30 years restricts innovations for herbicide use in weed management systems, blocking the sustainable transition of territories. The sociotechnical system theory was chosen as the analysis framework to identify obstacles in supply chains. As the issue cut across the supply chains at the scale of the territory, this framework was completed, for the first time, by a study of the existing links between supply chain innovation strategies and the territory through its spatial, organisational and conceptual dimensions. Interviews with supply chain actors and a review of the grey literature were analysed using this framework. We show that the development of innovations, their type and the network of actors producing them were defined within each supply chain, according to their own objectives, with few exchanges at all levels of the territory. The efficiency of such development depended on the extent to which the supply chains are structured and, particularly, on their degree of integration and the strength of relationships between stakeholders. Indeed, watershed scale objectives are not taken into consideration in changes of practice. In this way, we identified lock-in constraining innovations design taking into account the objectives of the impact area (watershed) across supply chains for the first time.
\end{abstract}

Keywords Pollution $\cdot$ Herbicide $\cdot$ Weed management $\cdot$ Socio technical system $\cdot$ Lock-in

\section{Introduction}

Herbicides are the most used pesticides worldwide (Duke et al. 2018). Herbicides seriously contaminate water by filtration processes to aquifers (Rodriguez and Araujo Leon 2018) and surface flows to rivers (Masiol et al. 2018). Water decontamination processes exist (Maroušek et al. 2019), but are expensive, so upstream contamination through the use of

Pauline Della Rossa

paulinedellarossa@gmail.com

Cirad, UPR HortSys, F-97285 Le Lamentin, Martinique, France

2 HortSys, Geco, Cirad, Univ Montpellier, Montpellier, France, Montpellier, France

3 UMR SAD-APT, INRA, AgroParisTech, Université Paris-Saclay, 75005 Paris, France

4 Cirad, UPR HortSys, F-34398 Montpellier, France

5 Cirad, UPR Geco, F-34398 Montpellier, France herbicides in agricultural production needs to be avoided. Reducing their use is not simple, as the contributions of research to weed control remain dominantly chemical (Harker and O'Donovan 2013). Agricultural innovations that reduce herbicide use do exist, but do not appear to be able to establish themselves durably in the cropping systems, as suggested by the stability of herbicide consumption in France (Dubois and Parisse 2017). This context raises the question of how to modify agricultural practices to reduce technical environmental impacts. The agronomy innovation literature mainly concerns technical changes at the plot scale, and fails to consider the institutional and political dimensions of crop protection between regional and national levels (Schut et al. 2014). Therefore, reducing the negative impacts of agriculture, such as herbicide pollution of rivers, occurs at territorial scales.

Transition theories consider both sociotechnical systems whose study focuses on areas that fulfil particular societal functions, in our case, agriculture, and also innovation systems by studying actors involved in innovation (Markard et al. 2012). In work on practice changes in agriculture, technological lock-in (Cowan and Gunby 1996), followed by sociotechnical transition (Geels 2004) frameworks, has been 
used to identify lock-in mechanisms of the "dominant regime" against certain practices despite their being identified as favourable to system sustainability. According to Geels (Geels 2004), a "dominant regime" is a system of rules, actors and material artefacts that apply to an entire sector of activity (in our case a supply chain). Rules govern relations between the elements of sociotechnical regime (such as actors-peopleand artefacts-objects-). They are either formal (laws, contracts), normative (standards, responsibilities, values) or cognitive (beliefs, cognitive routines, technological paradigms). The alignment of these rules stabilises the regime. The rules have been progressively shaped by interactions between the different actors participating in the sociotechnical regime. This creates a path dependence mechanism (David 1985) as the initial choices are reinforced over time through the interactions which stabilise common rules. This system reinforces itself resulting in locking phenomena which prevent radical innovations. A transition can occur when the regime is destabilised, which opens up opportunities for radical innovations. Due to path dependence, farming practices evolve in response to triggering events (Sutherland et al. 2012).

The analysis of sociotechnical transition has mostly concerned the development of innovative cultural practice or group of practices such as genetic engineering (Vanloqueren and Baret 2009), permaculture (Ingram 2018), or innovative interactions between production and downstream supply chain such as geographical indications (Belmin et al. 2017). These studies show that barriers to transition are interconnected and occur at every link in the value chain (Meynard et al. 2018), but do not examine the impact of these barriers on the ecological transition of a territory. Introducing environmental questions, such as the quality of water courses, requires considering the territory in its economic, social and environmental context to enable coherent and sustainable development according to the definition of (Emas 2015). This differs from the conventional approach to sociotechnical systems, by way of the dynamics of regimes and their disruptions, which, according to Duru et al. (Duru et al. 2015), poorly accounts for collective management of environmental resources. Indeed, supply chains use resources of territories, but do not always take environmental impacts into account (Madelrieux et al. 2017), because current methods of scaling agronomic innovations do not account for interactions between biophysical and social, economic and institutional factors, which regularly result in negative environmental impacts, such as river pollution (Wigboldus et al. 2016). This is why identifying and understanding interactions between supply chains and territories is still a challenge for research.

A territory is a geographical concept we studied based on a watershed. A watershed is a geographical area implying differentiation and spatial coordination of practices, linked by continuous hydrological processes linking the farm to the river (Soulard 2005). The territory can be read through three dimensions (Laganier et al. 2002): (i) Material, as an area endowed with properties that are natural or result from development of the area by actors in society; (ii) Conceptual, as a history and heritage, along with the representations and perceptions of social groups of the present and of the future of that area; (iii) Organisational, as an entity endowed with an organisation of its political and institutional actors, and of the multiple interrelations linking them.

Reducing herbicide pollution in water lends itself well to considering the territorial dimension where the watershed in all its aspects and the supply chains meet and oppose each other by combining actors, artefacts and specific rules: in a watershed, water quality is at stake (impacts), while technical and economic choices (pressures) occur in the supply chains. The aim of this study was to understand how the components of the regime prevailing in the sectors held back innovations for more sustainable weed management systems to reduce the use of herbicides in that territory. Our hypothesis is that the dominant regime of herbicide use is driven by supply chains objectives, blocking other regimes from radical innovations using less herbicides and therefore blocking the sustainable transition of territories (Madelrieux et al. 2017). The study of the changes in agricultural practices makes it possible to understand how certain types of projects, in our case territorial development projects, succeed or fail in influencing changes in agricultural practices (Sutherland et al. 2012).

The study was conducted in a watershed in Martinique where Della Rossa et al. (Della Rossa et al. 2017) previously demonstrated the relevance of the watershed scale to explain the chronic pesticide pollution. In a similar context, Mottes et al. (Mottes et al. 2017) showed that herbicides were so intensively applied at watershed scale that they resulted in water pollution. The tropical conditions worsen weed problems and pollution levels in water are high.

The rest of the paper is organised as follows: first, we present our analytical framework and the characteristics of the study area, and then break our results down into two major parts. One part analyses diversity of practices according to (a) how farmers use herbicides, (b) which actors influence farmers' decisions to manage weeds and the relations between actors, (c) the rules and artefacts which maintain the current levels of herbicide use. The second part examines the case of a current innovation to show how interweaving of the components in the sociotechnical regime hold back innovation in weed management, and suggests some levers for novel alternatives to herbicides in the watershed (Fig. 1).

\section{Material and method}

\subsection{Analytical framework}

In this study, we focused on a Error! Reference source not found.system composed of a watershed; the farmers who 
Fig. 1 a, b The quality of the river is affected by herbicide practices over the watershed. Pollution diffuses leads us to highlight lock-in effects for ecological transition, at the scale of a territory. We want to know if objectives of supply chains meet the objectives of territories for innovation design in weed management
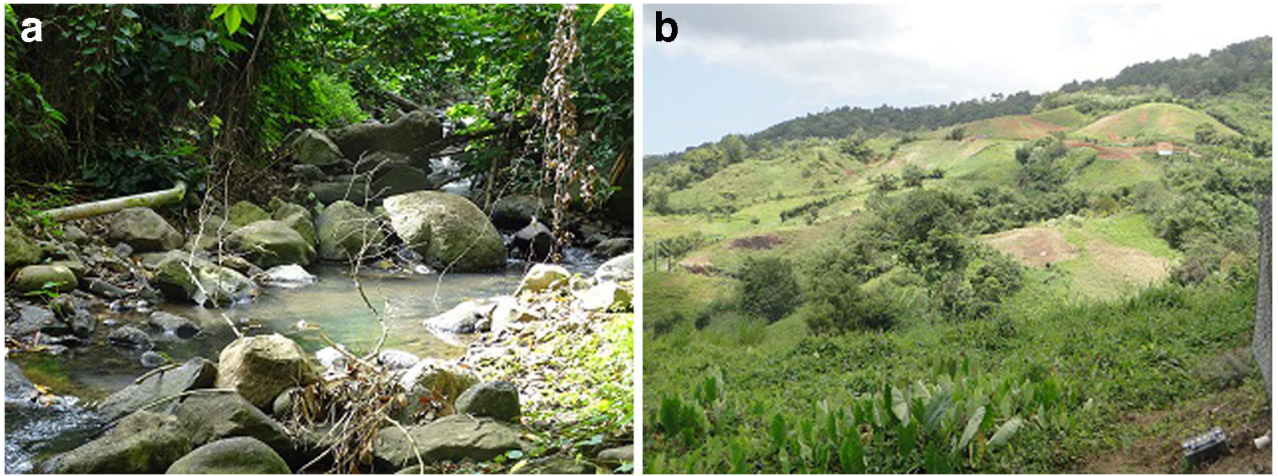

grow banana, sugar cane and garden vegetables; and the components of the supply chains which place the agricultural product of the watershed on the market.

Farmers are at the intersection of supply chains and the territory as producers in the supply chains and as actors in the sustainability of the territory's resources. Under this double influence, they change their cropping systems (in our case using more or less herbicide) depending on their resources and on the rules which structure their actions.

To highlight lock-in aspects of the regime of herbicide use on farms, we chose a framework combining sociotechnical and territorial conceptual frameworks (Table 1).

We saw that the elements of the sociotechnical framework regime according to Geels and the elements of the territory framework shared certain feature the following: the actors correspond to the organisational dimension of the territories; artefacts on the material dimension of territories and rules on the conceptual dimension of territories (Table 1 ). Our analysis of the actors, artefact and rules can be applied to the two analytical frameworks we used to study our system.

We defined the rules, actors and artefacts at the watershed scale for the three components of our system, the supply chains, the farmers and the territory.

The supply chain is studied not only through (i) its networks of actors who control crop production, and the distribution of added value, but also the dissemination of information between actors, up to the farmers; (ii) the accessibility of artefacts which controls technical choices; (iii) the alignment of the rules around the objectives of the most influential actors in the sector.

The farmers are studied through (i) their networks of actors, linked to their supply chains and also their relations with other farmers in their vicinity who may influence their decisions; (ii) their material artefacts which require investment and hence longterm use, and conditioning new activities to be complementary or not interfering with the use of artefacts; (iii) the alignment of the rules in order to fulfil their operating objectives.

The territory is studied through (i) the actors specific to its development, related to the actors of the agricultural sector to a greater or lesser extent, (ii) the territories natural resources and the activities that can influence them, (iii) the alignment of the rules needed to meet territorial objectives.
The diagram (Fig. 2) shows the meta-coordinates of the sociotechnical regime according to Geels (Geels 2004), who distinguishes technological, user and market, socio-cultural, policy and science sub-regimes, building the dominant regime through their meta-coordination. Four scales of action are defined: the farm, the watershed, the department of Martinique and the outside of the island.

Sub-regimes are transverse to scales and most actors are not present in the watershed, but have an influence on it. Consequently, the actors we studied are beyond the watershed scale, and we have to study the sociotechnical regime at the scale of Martinique to understand its impact on the watershed.

\subsection{Data acquisition}

\subsubsection{Study area}

This study was conducted in the Galion watershed of Martinique for three reasons. First, because it involves a river contract, an integrative project that according to Boiffin et al. (2014) is essential to develop organisational dimension at the territory scale; second, because major agro-pedo-climatic conditions of Martinique are represented in this watershed; and third, because river pollution by pesticides is monitored (OPALE observatory, (Mottes et al. 2019)).

The Galion watershed $\left(45 \mathrm{~km}^{2}\right)$ is located on the northern Atlantic side of Martinique. It is split into three agro-pedoclimatic zones. The upstream zone is characterised by steep slopes, high rainfall (4500 $\mathrm{mm}_{\text {year }}{ }^{-1}$ ), young volcanic soils (andosols) and, in particular, diversified farming (to produce diverse food crops for the local market) on small areas. The middle zone is characterised by steep to moderate slopes, medium-sized farms specialised in banana (Musa acuminata), and some small diversified farms, with moderate rainfall (3500 $\mathrm{mm}_{\text {year }}{ }^{-1}$ ) and intergrade soils between andosol and ferralsol. The downstream zone of the watershed is characterised by an alluvial plain, the existence of a large mechanised sugarcane (Saccharum officinarum) and banana farms, with a few steep slopes on which some small, non-mechanised sugarcane farms can be found, with low rainfall (1500 $\mathrm{mm}_{\text {year }}{ }^{-1}$ ), and mainly ferralsol. The 1000 ha 
Table 1 Conceptual analysis framework

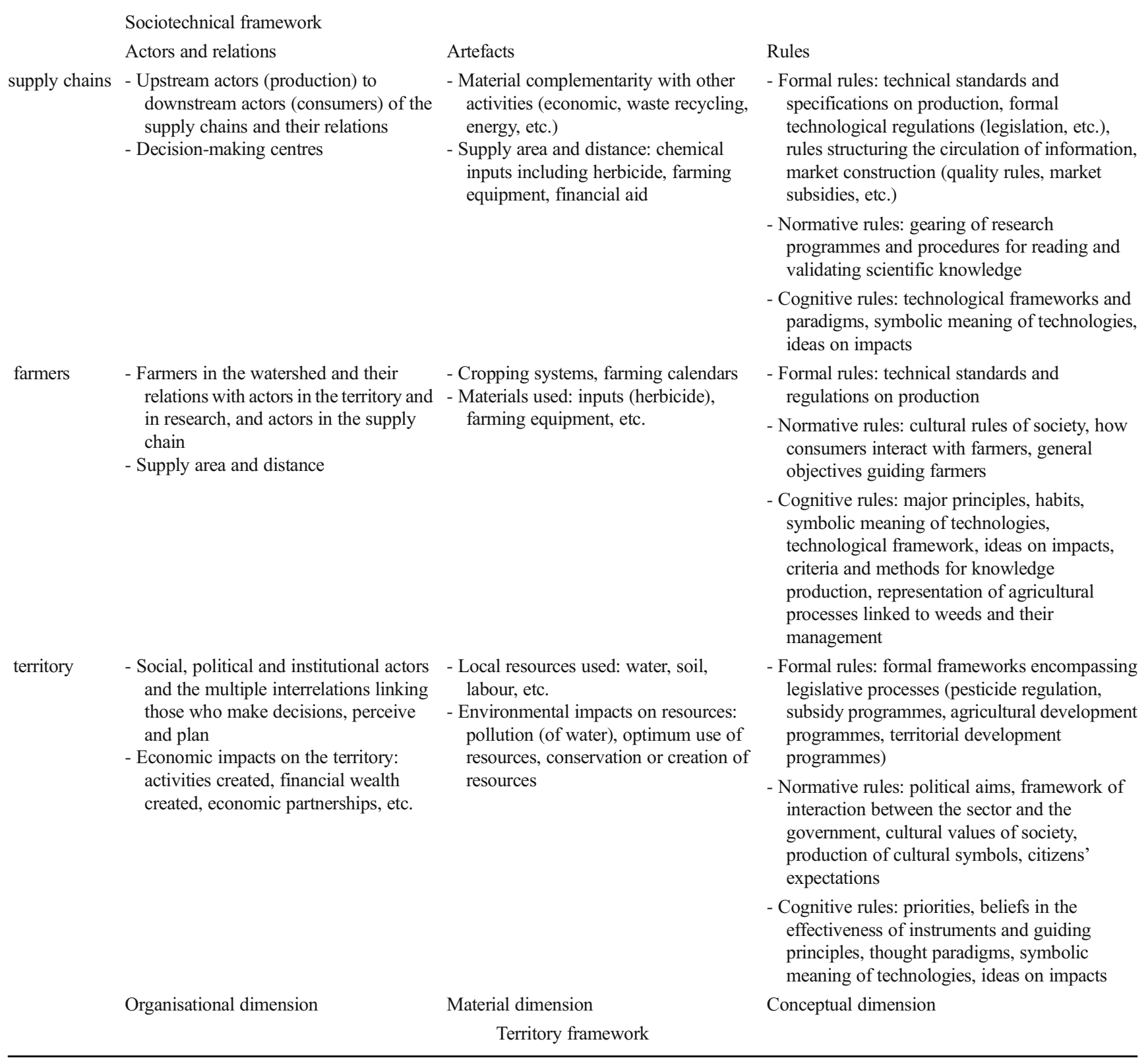

farmed in the Galion watershed by 141 farmers were broken down as follows: $45 \%$ were cropped with bananas for export (500 ha for 21 farms), $35 \%$ with sugarcane (370 ha for 38 farms) and the remaining 20\% were small farms (less than 4 ha, 82 farms for $130 \mathrm{ha}$ ) practising diversified farming.

Actors in the Galion watershed have signed a technical and financial agreement for sustainable management at the scale of a coherent hydrographic unit, here the watershed. This type of territorial development programme is called a river contract. The Galion river contract is unique in Martinique and brings together 30 actors in the agricultural, industrial or institutional sectors. Its main objective is to improve the quality of the Galion River.

\subsubsection{Sampling and surveys}

We identified the actors of the Martinique farming sector and of the territory, linked to herbicide use and water quality, in two participatory workshops (17 people from technical institutes, territorial management, producer organisations, supply chains, interbranch and state institutions and research). We conducted semi-directive interviews with these stakeholders and farmers in the watershed between 2014 and 2017 (23 surveys for famers in the Galion watershed, 9 export banana, 7 diversified, 7 sugarcane, 22 surveys of actors from the farming and territorial sectors comprising 1 research centre, 7 technical institutes, 4 producer groups, 1 pesticide distributors, 1 water manager, 2 State 
Fig. 2 Diagram of our regime's actors according to their scale of action (farm, watershed, Martinique, Continental France) and to their meta-coordination in the dominant regime from Geels (2004). At the farm level, a farmer takes technical decisions. At the watershed scale, farmers can be connected through network (formal or informal) or through physical processes
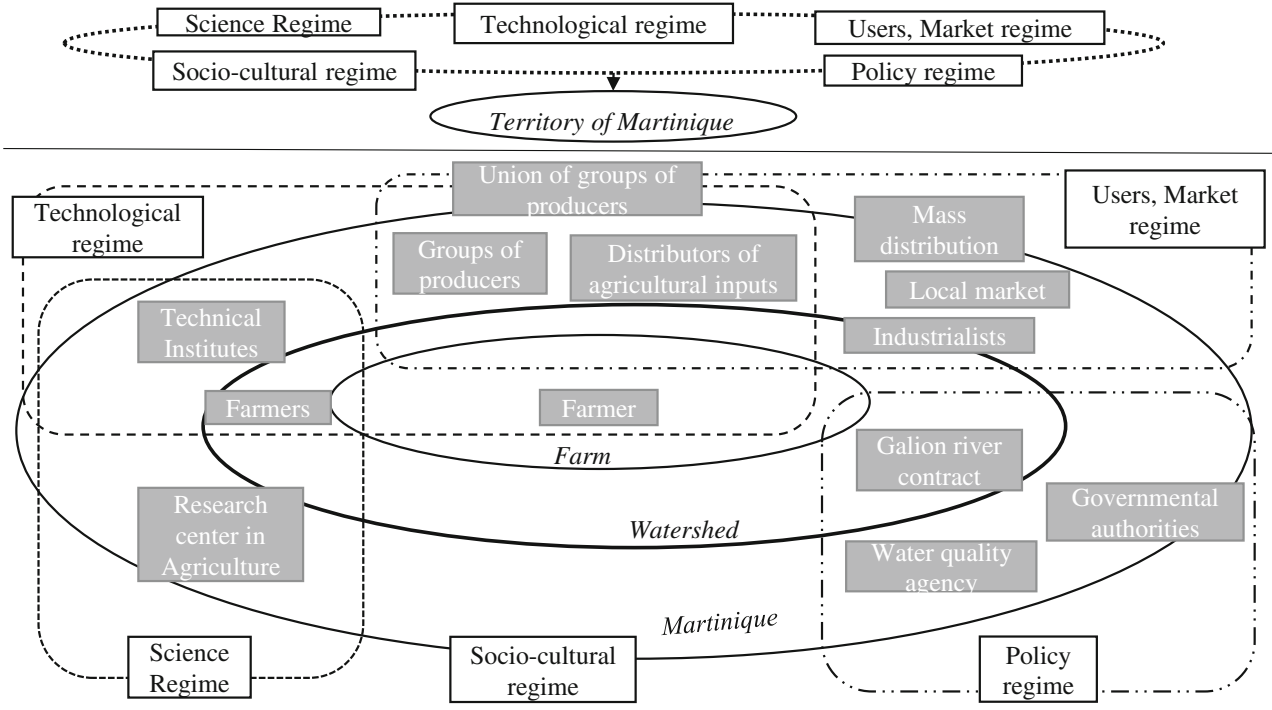

organisations, 1 territorial innovation service). Some actors were interviewed more than once. The interviews sought to discover the following:

- Quantitative aspects of herbicide use (quantity of herbicide active ingredients in $\mathrm{g} \mathrm{ha}^{-1}$ ) used on farms located in the watershed concerned;

- The relations between actors within their networks and their effects on changes in weed management practices among farmers in our watershed;

- The obstacles and levers for technical innovation arising from rules governing Martinique's farming sector.

A detailed analysis of the grey literature completed the information gathered in the interviews. In the grey references (see Table 2), we studied 5 topics: supply chains (Evaluation of Sustainable Banana Plan 1, Specifications of the certification in supply chains (GlobalGap, AOC rum, Organic Agriculture, supply chains contracts), farmers (Technical documentation provided by the supply chain on agricultural systems in Martinique, thematic files on agriculture in Martinique per sector) and territory (programmes and guidelines for agricultural development promoted by the State, European Development Programmes for the outermost regions of the European Union, water quality information, Galion river contract).

We derived normative, formal and cognitive rules from these documents and from interviews with actors.

\subsubsection{Data processing}

We studied the network of actors according to the qualitative intensity of the relations. First, we estimated factual elements (organigram of organisations, cross-participation in development programmes, contractualisation, programming of activities, decision-making process, etc.). Second, we estimated the influence of the actors in the farm trajectories, according to the farmers in Galion watershed.

We filled in the analysis grid (Table 1) from audio recordings of interviews and their partial retranscription, plus information obtained in our analysis of the grey literature (Table 2).

The average quantities of active ingredient used per hectare per year on 23 farms (9 export bananas, 7 diversification, 7 sugarcane) were calculated by summing all the quantities $\left(\mathrm{kg} \mathrm{ha}^{-1}\right)$ of active ingredients in the herbicide used on all plots, all crops combined, on each farm over a year, and then dividing the total by the respective cultivated areas on each farm.

We did not observe any major changes in the way the actors talked about the subject in 2014 and in 2017; only a few isolated farmers had changed their practices and there was no perceptible general trend.

\section{Results and discussion}

Table 3 summarises the elements of the socio-technical regime of the three supply chains described in the previous sections, which maintain the use of herbicide.

\subsection{Dominant chemical surface weeding}

The interviews with the farmers revealed three types of cropping system: sugarcane monocultures (semi-perennial crop harvested each year, with replanting every 5-7 years), banana monocultures (semi-perennial crop producing a bunch every 910 months; with replanting every 5 to 7 years, after 1 to 2 years of fallow) and diversification agriculture (combining orchards and mixed cropping of roots, tubers, vegetables, etc. in rotation 
Table 2 Major websites for the documents available online

Specification of the certification in supply chains

Technical documentation by supply chain on agricultural systems in Martinique, thematic files on agriculture in Martinique by sector

Programmes and guidelines for agricultural development promoted by the State, European Development Programmes

Water quality information

Galion River Contract
Global Gap: https://www.globalgap.org/uk_en/for-producers/globalg.a. $\mathrm{p}$./integrated-farm-assurance-ifa/crops/FV/

AOC rum: https://www.inao.gouv.fr/show_texte/4211

Organic Agriculture: https://www.agencebio. org/wp-content/uploads/2018/11/RCE_BIO_834_2007_oct08.pdf

Banana Farmer Manual: http://www.it2. fr/documentation/manuel-du-planteur-fr/

Evaluation du Plan Banane Durable: https://agriculture.gouv. fr/sites/minagri/files/documents/pdf/Plan_banane_durable_1_Evaluation Bilan_2014_cle8cc958.pdf; https://agriculture.gouv. $\mathrm{fr} /$ sites/minagri/files/documents/pdf/Plan_banane_durable EvaluationPBD1 rapportevaluation L3 cle094f $\overline{4 b}$.pdf; https://agriculture. gouv.fr/sites/minagri/files/documents/pdf/plan_banane_durable_ Evaluation_PBD1_Recommandations_L4_cle8778b8.pdf; https://agriculture.gouv.fr/sites/minagri/files/plan_banane_durable_ evaluation_pbd1_synthese_15.pdf

Banana: http:/www.it2.fr/documentation/guides-techniques/

Sugar cane: http://agritrop.cirad.fr/543040/; communications personnelles (les sites des CTCS sont maintenant introuvables)

Diversification: https://martinique.chambre-agriculture.fr/fileadmin/user upload/National/FAL_commun/publications/Martinique/Actes_seminaire pour_une_definition_collective-2015.pdf; http://daaf.martinique.agriculture. gouv.fr/IMG/pdf/Agriculture_Bio_Martinique_cle42a815.pdf; https://martinique.chambre-agriculture.fr/fileadmin/user_ upload/National/FAL commun/publications/Outre-Mer/AN-TI-KOUT-ZIE_Agriculture Biologique_2016.pdf; https://martinique.chambre-agriculture. fr/fileadmin/user_upload/National/FAL commun/publications/Martinique/EPEĀD_Synthese.pdf; https://martinique.chambre-agriculture.fr/fileadmin/user_ upload/National/FAL commun/publications/Martinique/ETUDE PREALABLE_EN_VUE_DE_LA_VALORISATION_DES PRATIQUES_ET_DES_PRODUCTIONS_TRADITIONNELLES_2014. pdf

POSEI: http://www.odeadom. fr/wp-content/uploads/2019/02/POSEI-2019-fusionné.pdf

PDRM: http://www.martinique.developpement-durable.gouv. $\mathrm{fr} / \mathrm{IMG} / \mathrm{pdf} / \mathrm{ESE}$ _finale_FEADER_Martinique_05092014_cle2e6195.pdf

http://www.observatoire-eau-martinique. fr/documents/ODE972-Rapport-campagne-RCS-2017-VF-03-09-18.pdf

https://www.contratderivieredugalion.fr/une-vision-durable/ or intercropped). Figure 3 shows the average quantities of herbicide used by each type of farm per hectare and per year.

All the cropping systems rely on herbicides (Fig. 3). Banana farms use more herbicides on average, with relatively low variability indicating a production system which relies on herbicides with few variations in practices. Diversification comprised a wide range of herbicide amounts applied, linked to the diversity of production systems. In sugarcane, the largest sugarcane farm (450 ha) used large quantities of herbicides, while small sugarcane farms (less than $5 \mathrm{ha}$ ) replaced herbicide use with brush cutter as much as possible, because of limited available cash. This made it possible for one farmer to not use any herbicide. The variability of herbicide use within each cropping system indicates that other factors than the cropping system such as the size of the farm, or the mechanisable area, are taken into account in the choice of weed management practices.

\subsection{Actors and networks: organisation per supply chain}

\subsubsection{Institutionalised networks}

The exchanges between stakeholders (notably farmers, producer groups, technical institutes) concerned the distribution of products, financial subsidies, information (market, prices, etc.) and technical advice, as well as negotiations with the public authorities and middlemen (wholesalers, medium and mass distribution). These exchanges were tightly organised in 
Table 3 Summary of the three case studies (banana, sugar cane and diversification supply chains) according to their elements of the sociotechnical regime, i.e. actors, artefacts and rules

\begin{tabular}{|c|c|c|c|c|}
\hline & & Banana & Sugarcane & Diversified \\
\hline \multirow[t]{6}{*}{ Actors network } & \multirow[t]{3}{*}{$\begin{array}{l}\text { Technical assistance of } \\
\text { farmers }\end{array}$} & $\begin{array}{l}\text { Centralised marketing by a union } \\
\text { of producer groups }\end{array}$ & $\begin{array}{l}\text { Marketing dispersed in the } 8 \\
\text { processing units }\end{array}$ & $\begin{array}{l}\text { Very dispersed marketing and } \\
\text { few farmers in groups }\end{array}$ \\
\hline & & $\begin{array}{l}\text { A producer group to defend } \\
\text { farmers' political and } \\
\text { economic interests }\end{array}$ & $\begin{array}{l}\text { A group of producers to defend the } \\
\text { political interests of farmers }\end{array}$ & $\begin{array}{l}\text { Several scattered producer } \\
\text { groups struggling to defend } \\
\text { the interests of their farmers }\end{array}$ \\
\hline & & (a) & (b) & (c) \\
\hline & \multirow[t]{2}{*}{$\begin{array}{l}\text { Contractualisation for } \\
\text { financial inducement }\end{array}$} & $\begin{array}{l}\text { Continue from upstream to } \\
\text { downstream, with integrative } \\
\text { contract }\end{array}$ & $\begin{array}{l}\text { Continue from upstream to } \\
\text { industrialist, with production or } \\
\text { marketing contract }\end{array}$ & $\begin{array}{l}\text { Continue from upstream to } \\
\text { downstream, with purchase } \\
\text { and sale contract mostly }\end{array}$ \\
\hline & & (d) & (e) & (f) \\
\hline & $\begin{array}{l}\text { Informal network on the } \\
\text { watershed }\end{array}$ & \multicolumn{3}{|c|}{$\begin{array}{l}\text { Innovations more effective than networks linked to institutional actors, Exchanges of knowledge between } \\
\text { the farmers structured by the supply chains }\end{array}$} \\
\hline \multirow[t]{3}{*}{$\begin{array}{l}\text { Rules and } \\
\text { artefacts }\end{array}$} & \multirow[t]{2}{*}{$\begin{array}{l}\text { Driving innovation in } \\
\text { supply chains in } \\
\text { Martinique }\end{array}$} & $\begin{array}{l}\text { Innovation driving by an } \\
\text { ecological transition that keeps } \\
\text { monocultural system }\end{array}$ & $\begin{array}{l}\text { Innovation driving by varietal } \\
\text { selection and mechanisation that } \\
\text { keeps the monocultural system }\end{array}$ & $\begin{array}{l}\text { Innovation driving by an } \\
\text { agroecological orientation } \\
\text { that favours the } \\
\text { diversification of farms and } \\
\text { plots }\end{array}$ \\
\hline & & (h) & (i) & (j) \\
\hline & $\begin{array}{l}\text { About agroecological } \\
\text { transition in territories in } \\
\text { Martinique }\end{array}$ & \multicolumn{3}{|c|}{$\begin{array}{l}\text { Programmes to reduced pressure according to supply chains objectives } \\
\text { farmers' supply chain organisation induces an unequal agroecological transition in the region }\end{array}$} \\
\hline
\end{tabular}

networks by the supply chain, and two structuring aspects of those networks affected innovation trajectories: the intensity of relationships between the actors and the degree of contractualisation between actors.

Access to innovation is linked to the intensity of relationships between the actors, notably through technical, financial and organisational support provided to farmers. The banana

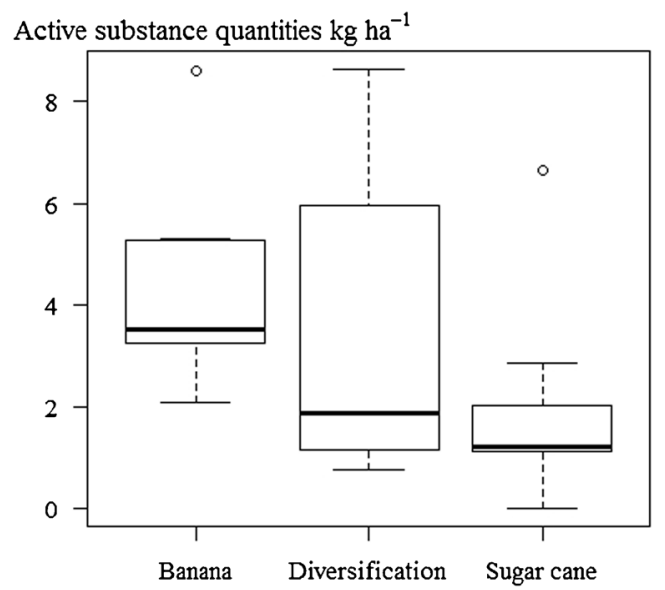

Fig. 3 Farmers' uses of herbicides in Galion watershed, according to the cropping systems ( 9 export banana farms, 7 sugarcane farms, 7 diversification farms). Averages showed that the export banana cropping system used more herbicides than the others. Diversification covered a wide range of production systems and consequently of weed management practices supply chain had a dense network of longstanding relations between actors, thanks to the existence of a Producer Group of banana (POB) and a Federation of Producer Groups of Banana (FPGB), which centralise the political and economic interests of farmers: "all services are offered to the planters, central purchasing, negotiation with the suppliers, we negotiate the freight contract. In addition, there is all the technical and administrative follow-up. We have a subsidy program, we defend the measures that are most adapted to the supply chain"(POB); "By creating the federation of groups, we have a single marketing office here in Paris, so a single price referenced for the bananas from Guadeloupe and Martinique, an industrialist that belongs to the FPGB, and one phone number, here, the FPGB. And behind was also restructured the production, a PO in Martinique, and one in Guadeloupe" (FPGB) (Table 3(a)). In the sugarcane network, marketing was not centralised and the processing units were independent ( 7 rum distilleries and 1 sugar refinery). In 2014, "The planters decided to get together to create a structure that will defend them at the level of state administrations" (POS). However, this group of sugarcane producers (POS) mainly seeks to defend production conditions with government institutions rather than commercial condition with industrialists. Finally, the possibility of action of POS remains limited: "POS have little financial means. We do not have as much land as banana growers. The cane supply chain does not have the same financial means as the banana supply chain" (Sugar cane and rum 
producer) (Table 3(b)). In the diversified crop sector, only $20 \%$ of farmers belonged to producer groups spread over 8 structures (cooperatives, associations, groups or POD), incorporated in an interbranch organisation since 2010, that suffered from governance problems. This situation seriously reduces the chances of the political and economic interests of farmers being taken into consideration and renders the circulation of information difficult: "the diversification supply chains does not supply the financial counterpart, unlike cane and banana, which is required to obtain European funds" (TIB); "for supply chain diversification, this is a big problem, $80 \%$ of producers do not belong to a producers group. Normally the Agricultural Chamber is in charge of these farmers. I doubt that the chamber can contact all of them, as this represents thousands of people. The chamber has a list of farmers. But who knows if the phone numbers are still active" (TIB) (Table 3(c)). These structural differences between supply chains influenced the technical advice and the innovations derived from research. Banana farmers benefited from structured technical assistance and from active research. A total of $67 \%$ of the banana farmers in the watershed we interviewed acknowledged that the banana technical institute (TIB) influenced their learning trajectory. The research centre maintained close relations with the TIB, but weaker relations with the technical institutes and farmers in the diversification supply chains, as they are so scattered. Almost no relations were reported between the sugarcane technical institute and the research centre, due to the absence of a researcher specialised in sugarcane in Martinique. According to the sugarcane farmers in the watershed, the sugarcane technical institute (TIS) was not concerned with smallholders but focussed on large-scale farmers due to lack of funding, which obliged the institute to abandon personalised follow-up and only carry out trials on large farms able to lend them equipment.

The degree of contractualisation in the supply chain also influenced the ability to innovate. The form of contractualisation will determine the degree of vertical coordination of actors in a supply chain (Cholez et al. 2017). But weak vertical coordination can lock the sociotechnical system against radical innovations because the added value is not evenly distributed to all actors, especially farmers (Fares et al. 2012). However, a farmer will be encouraged to implement sustainable practices, which are often more expensive, if the financial valuation of his production allows him to do so.

In the case of bananas, criteria that are essential for consumers, including fruit sensory quality, led to increased contractualisation over time with the final establishment of an integrative contract with a long-term commitment period, delegation of production decision-making rights and pooling of production resources (Cholez et al. 2017): "FPGB is in charge of the specifications. It is based on European regulations. Then you take decisions according to this reference, and you adapt it according to the needs of the mass distribution, which will be based on the size of the fruit (large, small means) and packaging" (FPGB). Knowledge of the effect of interactions between practices and environmental components in the field, and during ripening on fruit quality, led to forecasting optimum harvesting periods. In addition, the nine FPGB ripening units checked sensory quality throughout the chain, from plot to sales point. This structuring of the supply chain focussed on product quality, and the strong negotiating power of its upstream component enabled added value sharing that was quite favourable for producers and could have enabled farmers to fulfil new demands for more environmentfriendly production by acting upon the added value lever (Fares et al. 2012) (Table 3(d)). For sugarcane, added value mainly came from the product being processed by the industrialist, especially rum, with production or marketing contract between farmers and industrialists, with an annual commitment contract, signed before the production campaign, with pooling of certain production resources (Cholez et al. 2017). In such a case, according to Fares et al. (2012), farmers had little incentive to change their practices because the downstream part of the chain was not committed to dynamics of environmental transition including the fair distribution of added value, as revealed by opinions expressed by these actors: "The cane supply chain suffers from a lack of financial means. All the money goes to rum. Rum makes money, no problem. You should see their advertising campaigns. But there is no financial return for sugar cane and that's really a problem." (State Department of Agriculture); "if you want to make money from sugar cane, you have to have a distillery. Because it's the rum that makes money. The small planters have a lot of financial difficulties, you cannot make a living just growing cane, or you have to have a huge farm" (TIS) (Table 3(e)). For the diversification supply chain, the situations depend on whether the farmer is a member of a producer organisation or not. These farmers sell on the local market and often have sales purchase contract, which is an instant contract signed after harvest, with no pooling of production resources. This situation results in weak support for developing technical skills (Cholez et al. 2017) but does leave room for innovation: "fewer intermediaries, therefore more income on the selling price, which makes it possible to increase the workforce available on the farm and we also have better stock management. Having a small area and marketing in short circuit means we have a stronger ability to innovate" (Chamber of Agriculture) (Table 3(f)).

\subsubsection{Informal networks in the watershed}

We saw varied local farmer networks in the watershed including an economic interest group, family network, a farm machinery cooperative or based on different forms of collective action (informal mutual assistance system, or association for a local market). Interviews with farmers showed that the 
networks made more effective innovations than networks linked to institutional actors (technical institutes, producer groups). In addition, the innovations exchanged in these networks were often produced or adapted by the farmers themselves as found by Goulet (2013). Our results confirm those of Dolinska and d'Aquino (2016), who reported that peers are the most widely used source of knowledge by farmers. For instance, one banana farmer in the watershed completely replaced herbicides with brush cutter weeding. This innovation was then spread to another three farms thanks to exchanges in an economic interest group. This innovation was then gradually further disseminated via some informal networks (family, friends) and applied on three additional banana farms in the watershed. However, at the watershed scale, exchanges of knowledge between the farmers remained structured by the supply chains and clearly constrained the differentiation in weed management practices.

Lastly, our network analysis revealed two key characteristics of the sociotechnical regime. The first was that the research and advice available differed depending on the supply chain, which led to an imbalance in the farmers' resources available for innovation as already shown by Biarnès et al. (2009). The second characteristic was that the structure of the network segmented by the supply chain (comparable with silo structure) fixed the scope of innovation to the domain of each supply chain. Novel practices were only sought within the existing cropping system, which restricted alternatives across the supply chains (Table 3(g)).

\subsection{A complex system of weed management artefacts and rules disconnected from local impacts}

In this section, we show that for the two monoculture supply chains (sugarcane and banana), the search for novel solutions to reduce herbicide use was either secondary or orthogonal compared with other objectives such as higher yields, harvest mechanisation, shorter fallow periods or disease control. Thus, the framework of existing cropping systems fixed innovations, to the detriment of more cross-territorial solutions. We will also show that these orientations determined the main lines of research of the technical institutes, research centres and their socalled "back-office" activities, where new knowledge and upstream references for advice to farmers were developed (Labarthe and Laurent 2013). Finally, we demonstrate that this commitment to accumulating knowledge in favour of the objectives and technologies targeted by the supply chain can strengthen technological lock-in over time (Labarthe and Laurent 2013).

\subsubsection{Uniformisation of banana practices}

Uniformisation of banana practices began with the Mallessard report (Mallessard 1998). This author linked quality and yield problems with a poor command of crop management sequences by some farmers. Starting from a wide range of cultivation practices, the stakeholders of the supply chain (POB, FPGB) decided to standardise them to improve quality and stabilise yields. The supply chain realised the environmental and health risks of using pesticides in 2000 with the chlordecone scandal (Lesueur Jannoyer et al. 2017). These two challenges - standardisation of practices and ecological transition-were translated into a set of specifications to be respected by all producers: the GLOBALG.A.P. quality standard (for mass distribution, and marketing), crop management sheets to be respected by farmers and the Sustainable Banana Plan (to reduce the use of chemical inputs) (POB interview: "We have several specifications. First, we have the planter's manual with all the technical itineraries that planters must respect. Then we have a quality repository. The quality standard that the planter must respect in relation to the category of banana. For each category, there are criteria according to the length of the grade, defects. Then, other specifications in the sustainable banana plan that engages all planters. So actions are defined and implemented to achieve the objectives of the sustainable banana plan"). The Banana Sustainable Plan reflected a partial transferral of dealings with environmental concerns from public actors to private actors in the supply chain, in return for public policies in their favour (Bonin and Cathelin 2014). These shifts were a sign of a strong desire for ecological transition in the supply chain, but let the private actors choose their own standards (Bonin and Cathelin 2014).

This explains why the technical innovation developed so far did not consider the impact of herbicide use on river pollution. The standards imposed access to the plot throughout the year for harvesting and for bunch care to ensure product quality, hence regular chemical weeding. Although a reduction in pesticides was sought, the Sustainable Banana Plan focused on the use of insecticides and nematicides, in response to the chlordecone scandal "It comes from a reflection aimed at answering issues that were gaining momentum (societal challenge with the case of Chlordecone) "(evaluation of the sustainable banana plan (Meiffren et al. 2014). This led to an innovation that was both agricultural and institutional, consisting in financially backing the planting of nematodefree vitro plantlets to renew plantations. This innovation introduced a period of 1 to 2 years of fallow between two banana crops in a cropping system that had previously been almost perennial "nematicides are responsible for $54 \%$ of the overall decline in products on both islands (75\% in Guadeloupe, $42 \%$ in Martinique). They fell sharply thanks to the generalization of vitroplants and sanitizing fallow" (evaluation of the Sustainable Banana Plan (Meiffren et al. 2014)).

It is also important to measure how the rules and standards arising from the organisation of the banana market affected these innovation capacities. Indeed, production costs in the French West Indies are higher than in other bananaproducing countries, due to six to 28 times higher wages 
(Bugaud et al. 2011). The supply chain therefore depends on standing out commercially (certification), but greatly depends on the subsidy regime like other European crops (Bonin and Cathelin 2014). The POSEI programme (EU Programme of Options Specifically Relating to Remoteness and Insularity) encouraged a global production quota system for the island, through aid calculated using a historical reference defined for each farmer. Each farmer had to maintain a minimum production level of $80 \%$ of the reference to receive aid corresponding to $100 \%$ of his historical reference.

Thus, at the scale of the island, production remained intensive and the aid system encouraged its maintenance as a monoculture. Monocropping was also constrained by two elements. First, the necessary compulsory treatment against Black Sigatoka, sprayed onto banana leaves (order July 31, 2000 by the French Ministry of Agriculture), and that prevented any combination with cash crops without approval for this treatment. Second, the pollution of soils with chlordecone restricting the intercropping with market garden and food crops (tubers) (Clostre et al. 2017).

Here again, the solutions for improving the environmental efficiency took place within the framework of the existing banana monoculture cropping systems, ignoring more territorial solutions (Table $3(\mathrm{~h})$ ).

\subsubsection{A sugarcane supply chain focused on varietal selection and mechanisation}

Innovation research in sugarcane was driven by varietal selection and mechanisation (Table 3(i)).

Varietal selection developed in 1952, with the creation of TIS, to prevent the uncontrolled introduction of foreign planting material (Mbolidi-Baron 2002). Priority was given to varietal selection with two objectives: (i) avoid pathogen attacks and (ii) mitigate the lack of production on the scale of the island, which is still topical (Mbolidi-Baron 2002). This partly explained why weeds were the only rivals to sugarcane. One of the selection criteria was suitability for mechanised harvesting, sometimes to the detriment of easier weed management. This happened to a famer who planted sugarcane selected by TIS using varieties originally from Reunion Island: "We've had a lot of rain, and these canes lodged, facilitating access to rats and creepers [...] whereas with blue sugarcane [local variety] which is nice and thick, we'd be able to have clean fields more easily" (interview with sugarcane farmer). Systematic herbicide use in sugarcane since the 1950s had influenced the sugarcane varieties disseminated. Some of the most sensitive varieties to herbicides had been eliminated or restricted to small areas (Mbolidi-Baron 2002). We also found that varietal selection remained the same today, reducing research on weed management innovation ("The role of TIS is an applied research role, bringing varieties from all over the world, such as China, Brazil, Barbados etc. all countries that create varieties. So the role of the TIS is varietal selection" (POS)). The lack of financial resources for sugarcane innovation research in Martinique worsened that situation ("the TIS lacks means, there is no money, or very little" (State Department of Agriculture)).

Mechanisation, especially harvesting, developed because this agricultural task was the most important in terms of cost and time (Mbolidi-Baron 2002). In the 1960s, sugarcane underwent a major crisis that marked the start of its decline, linked to disenchantment with farm work at the same time as an increase in wages (+ $60 \%$ between 1960 and 1965, (Bassereau 1966). quoted by (Mbolidi-Baron 2002)). Thus, sugarcane farms aimed to reduce work times, which were particularly high for harvesting. Accordingly, the supply chain rapidly started mechanising harvesting via TIS, which peaked in the 1990 s when $75 \%$ of harvesting on the island was mechanised. Large farms also remodelled fields to achieve the maximum possible level of mechanisation. Mechanisation remained a research priority for stakeholders in the supply chain, thus influencing alternative to herbicides. For instance, row spacing conducive to weed growth constrained innovation while mechanical weeding methods were promoted ("Experiments were carried out for three years, tighter rows were planted so that the canes were close and the weeds did not receive the sun. Except that it was difficult to harvest double rows of cane with harvesting machines that are designed to cut one row of cane, so there was often a lot of loss because you have to cut two rows, with more density, and that caused problems." (POS)). By facilitating work in the zones accessible to machinery (large, almost flat plots), smaller farms and/or in hillier zones did not benefit from innovations. Small sugarcane farmers therefore appeared to have little negotiating power in guiding innovations in the supply chain, even though they account for $19 \%$ of the cultivated area in our watershed, and 37 farmers were involved.

\subsubsection{Diversification farming, agriculture with little assistance}

Diversification farming in Martinique had always received less attention from the State. As the supply chains were less structured, there were a larger number of actors with different logic of change. Little information about these supply chains and their technical development was available. This type of agriculture was more rooted in the territory due to (i) its local outlets for almost all of its produce, providing $43 \%$ of fresh vegetables and $34 \%$ of fresh fruit consumed in 2015, and (ii) a larger number of farms (more than 2500) scattered throughout the territory.

Territorial managers or transversal agricultural stakeholders, such as the Chamber of Agriculture and the Martinique Territorial Authorities (MTA), promoted weed management rules. The latter has provided agroecological impetus since the 1990s, with the first Integrated Pest Management trials of the MTA's Agroecological Experiments Service, then at the beginning of the 2000s with comparative organic versus conventional crop trials. Since 2013, the remit of the Chamber of Commerce has been to develop the Organic Farming sector, backed up by 
institutional stakeholders such as MTA and the Martinique Food, Agriculture and Forestry Directorate. They strongly urge diversification farmers to convert ("then the missions of the centre evolved towards pesticide-free management, up to agenda 21 , where we started to work on crop rotation, associations, all to reduce pesticides used. Agenda 21 is an action plan for local authorities for sustainable development. So our missions have evolved towards a logic of sustainable development" (MTA's Agroecological Experiments Service); "organic farming is the Chamber of Agriculture's baby" (TIB)). However, the organic farming label was controversial among the diversification farmers on the island, as its specifications did not ban monocultures and certification was expensive (interview with the Chamber of Agriculture). Some small groups of farmers preferred to organise themselves in more or less formal groups to share a charter, which they promoted in short marketing channels. Faced with this situation, the Chamber of Agriculture considered its own label specific to so-called "traditional" farming, which prohibited chemical weed management. The Chamber of Agriculture defined traditional farming in Martinique as follows: "a system of diversification farming (excluding sugarcane and export banana), mixed cropping or mixed cropping-livestock farming with mainly food crops, intended for the local economy".

This "traditional" farming dominates in the upstream zone of the Galion watershed. There, the weed management rules were designed according to requirements of the local markets. The main outlets were via short channels, with 0 or 1 middlemen. This entailed a relationship with the customer that was often direct, and encouraged alternative practices to herbicides: "in the market, as we meet many consumers, people ask us how we work, they are curious to know what we use as inputs. In any case, the people who come to the markets are aware of such things. So we attempt to respect consumers" (interview with diversification farmer). In addition, some production was consumed on-farm, which encouraged farmers not to use pesticides. Formal residue standards were particularly strict in this supply chain due to soil pollution by chlordecone, which affects tubers and vegetables in contact with polluted soils (Clostre et al. 2017). To conclude, although diversification farming was very diverse and largely isolated, it entered into dialogue with consumers, and with operators in the territory and the farming sector, tending towards practices with little or no herbicides (Table 3(j)). However, the diversity of the farming systems and the lack of financial means made the search for adapted innovations difficult.

\subsubsection{A territory relying on structured supply chains for environmental transition}

The evolution of agricultural development policies over the last 20 years showed that the State has gradually relied on structured supply chains to guide ecological transition. As shown by Maury et al. (2013), the State institutional paradigm changed in 2006, moving from farming, and its multifunctionalities in the sustainability of territories, to refocusing solely on environmental impacts. This change resulted in programmes for the reduction in phytosanitary pressure, which was measured at the plot or farm scale, with no links to the socio-economic and spatial context of the farm. Gradually, there was a transfer of environmental responsibilities from the State to professional organisations, and the structured supply chains seeing their strategic position strengthened by their intermediary role. The Sustainable Banana Plan 1 was a typical example of this phenomenon. It was proposed by the actors of the banana supply chain (POB, FPGB) and research, and was subsequently approved by institutions (Ministry of Agriculture, department). This delegation of responsibilities to the supply chains sidelined farmers and actors who were not part of structured supply chains, like the diversification farmers.

The organisation of farmers in supply chains prevented the operational implementation of territorial development projects. This was reinforced by the fact that actors involved in a territorial initiative, such as the territorial communities or environmental protection agencies, cannot be initiators of projects with subsidised agroenvironmental measures. In addition, in the Galion watershed, smallscale sugarcane farmers did not benefit from support from supply chains, making ecological transition difficult on $19 \%$ of the arable area. Diversified farmers, who accounted for $12 \%$ of farmed land, were not sufficiently structured to benefit from enough State aid to undertake ecological transition. Therefore, agricultural development policies working for ecological transition failed to consider $31 \%$ of the farmed area in the Galion watershed (Table $3(\mathrm{~g})$ ).

\subsection{Hindrances to innovation: example of service plants in banana and sugarcane}

To sum up how the characteristics of the sociotechnical regime that we have described affect agroecological transition in a watershed like Galion, we delved deeper into the emergence and expansion of a recent innovation in banana and sugarcane crops: associated service plants (SP). This innovation, initially developed by banana researchers in 2008 (Research Centre, TIB) ended in an "associated cover crop" technical package transferred to sugarcane farmers in 2013.

The story began with a plant selection process in the Sustainable Banana Plan (2008) to reduce the length of fallow between two banana crop cycles. Later, the agronomic principle of associated service plants evolved to replace the weed population in crop interrows with a population of plants chosen for functional traits (Damour et al. 2014). The aim is to provide different services for the associated crop, notably preventing the development of undesirable weeds. Our survey 
showed that for banana, a non-native cover crop is installed before banana is planted (broadcast sowing with superficial soil tillage if mechanisable, or direct sowing), or in established banana crops (preferably by cuttings). In the case of native cover crops, weed selection was carried out in patches, selecting either mechanically, but mostly chemically, the plants to be destroyed. For sugarcane, native plants dominated which were always sown at the beginning of the crop cycle, either by broadcast sowing or with a seeder. In the following section, we detail the main components of the current regime restricting service plants in banana and sugar cane farms.

\subsubsection{Banana}

The need for access to the plot and the focus on reducing nematicide and insecticide use resulted in selecting service plants with the following functional traits: perennial and shade-tolerant to survive under banana cover for 5 years, resistant to trampling and the passage of machinery, not a host of the banana nematode $R$. similis. The "not a nematode host" trait was retained from plants selected for fallow, while the other functional traits were adapted to a plant grown under banana cover as opposed to a plant grown in a monoculture fallow (Lassoudière 2012).

Planting associated SPs entailed additional costs linked to the establishment and upkeep at the start of plant development, which was very labour-intensive. According to $\mathrm{POB}$, difficulties in establishing a plant cover started from a certain (more than 50 ha), when labour costs became too high and the organisational flexibility of the farm was too limited. A combination with cash crops to offset these costs was buried by both the presence of chlordecone in the soils which ruled out the use root and tuber crops, and the compulsory treatment against Black Sigatoka (Cercospora Fijiensis). Lengthening the life span of a banana plantation to pay off the investment over a longer period was risky because of the potential development of large population of $R$. similis and weevils (C. sordidus).

There were also availability problems for service plants. Concerning SPs that had to be imported, the only importer and distributor of seeds in Martinique reported the problems he encountered importing seeds at an affordable price for such a small market as Martinique "The French West Indies is a small market. For example for cover crops, we had to decide how many varieties should be imported. We explained to the supply chain banana that it is impossible to import 20 varieties of seeds because then we had to reduce the volume, so we would have even less bargaining power" (Distributor of agricultural inputs)). This is why he currently imports six to seven plants out of the 20 or so identified by the research centre and TIB. Currently, no nurseryman, regularly producing local SPs in significant quantities even though there is a potential market as actors across the sociotechnical regime, said they preferred native to imported plants. As a result, the farmers had to select or move patches of plant cuttings they had on their farm, or procure them by other means, from a neighbour's field, for example (interviews with export banana farmers). In general, actors in the banana supply chain increasingly selected wild spontaneous cover plants, which ultimately became the most widespread method among the farmers as it was less labour intensive, cheaper and did not require a plantation.

\subsubsection{Sugarcane}

Concerning sugarcane, the cover plant innovation inherited from the selection programmes was developed for banana. In this case, the plants had to be slow growing, withstand sunlight and be annual, in order to die when the crop cover closed, to avoid competition with sugarcane ("Because if the cover plant produces seeds, when it grows back, it will not grow properly. It's complicated, so I need a plant that does not tolerate shade. Not like banana where you need plants that tolerate shade" (TIS)). Lastly, the agronomic characteristics of the SPs selected for banana were not adapted to sugarcane. With sugarcane, growing a cash crop in the interrows had already been practised historically (Mbolidi-Baron 2002) and a few farmers grew oignon peyi (spring onion) or watermelons between the rows of sugarcane.

Like banana, planting SPs entailed additional costs which are barely offset by added value, which rather came rather from the processed product. In this sense, the first farmer to have tested cover plants in sugarcane also had a rum distillery ("We are farmers and industrialists. That is why we can be innovative. We are trying to get a head start on the narrowness of the market. We do not even make two percent of the rum in Martinique. For the European market, we are the first organic rum so we can value the rum" (farmer in organic farming interview)). In this case, the organic farming label for the rum, which the SPs helped to procure, helped to offset the extra cost of installing SPs (interview with organic farmer).

The issue of SP seed availability was all the more problematic in that only one farmer used SPs in sugarcane: "cover plant seeds are not easy to come by, because 2-3 orders per year are placed by the importer who centralizes orders mostly for banana, whereas our dates are not necessarily the same as banana. There are some seeds we'd have liked to test, but the import formalities were too complicated for just 1 or 2 bags, so the importer couldn't do it. So we use the same plants as those used with banana" (interview with organic farmer).

One last obstacle to developing this innovation in sugarcane is the farmers' perception of "weeds", which made it difficult to get sugarcane farmers to voluntarily grow weeds in interrows: "in interrows, farmers still have too much of a vision of competition (between plants), and are therefore less interested" (TIS interview). With the transfer of the cover plant innovation in fallow, banana farmers became aware of 
the benefits of cover plants for soil conservation. This is why banana farmers were much less reluctant to use cover plants in their interrows than sugarcane farmers.

Figure 4 summarises which aspects of the regime constrain the use of service plants in banana and sugar cane supply chains. Resulting from the interaction between actors, rules and artefacts, some elements of the socio-technical regime (orange outline) lock it against radical innovations, such as service plants. Banana farmers need access to the plot around the year, which constrains the type of plant to support trampling. The formal rules of the institutional actors, the European subsidies, the law on the treatment against Sigatoka and the maximum residue limits of chlordecone in vegetables maintain the monoculture system in banana, and the service plants cannot produce marketable commodities. The actors in banana research and advice have focused on reducing nematicide uses, so they need to find service crops that do not host nematodes. In cane, the added value is poorly redistributed by industrialists, financially constraining farmers in their innovations. Cane farmers have a negative representation of weeds in plot, which involves a small interest of farmers for service plants in their cane plot. The weakness of the financial resources of TIS and POS prevents the production of knowledge on cover plants in sugar cane supply chain. Finally, the sugar cane and banana supply chains of the French West Indies are a small market, which weakens their bargaining power, and which is why the seeds of service plants are expensive.

\subsubsection{Consequence for the Galion territory}

The organisation of agriculture in segmented supply chains scale affected the ability of farms in the territory to innovate. For cover plants, we showed elements holding back innovations in weed management as negative representation of weeds in plot for sugarcane, or the focus on reducing nematicide uses for banana (Fig. 4). In the watershed, 6 banana export farmers had tested or were testing associated SPs on part of their farm, 5 of whom selected wild plants. For sugarcane, only the large farm had tested in 2014 the combination with a cover plant installed at the time of planting. Thus, SPs developed in line with the banana model previously explained, mainly on banana areas of our territory but not on sugarcane areas. The market gardening areas did not seem to be involved in this transition. Thus, the main hope of changes in weed management through this innovation was likely only to involve banana farmers, i.e. $45 \%$ of the agricultural area outside grasslands. Sugarcane, a major herbicide user, was not a major actor in this innovation.

Therefore, the implementation of programmes of territorial development, such as a river contract, can enable supply chains to focus research on territorial objectives: "we do not specifically give advice to farmers just because they are close to a watercourse, unless there is a problem, for example in the context of the Galion river contract. Effectively, we will take specific actions for these farmers, in this area, because we are committed to this contract. Otherwise, all farmers can benefit from POB's advice, in a homogeneous way" (POB). This example shows that the multiplication of programmes of territorial development can encourage the ecological transition of the territories, according to the objectives of territory's actors rather than according to the objectives of supply chains actors (Table $3(\mathrm{k})$ ).

\section{Conclusion}

Some authors, mainly economists, have showed technological lock-in on pesticide use at a worldwide scale (Cowan and
Fig. 4 Diagram of obstacles induced by the sugarcane (green outline) and banana (yellow outline) innovation regimes. Herbicide use is maintained by some aspects of each regime (grey outline), thus inducing innovation lock-in for weed management (orange outline)

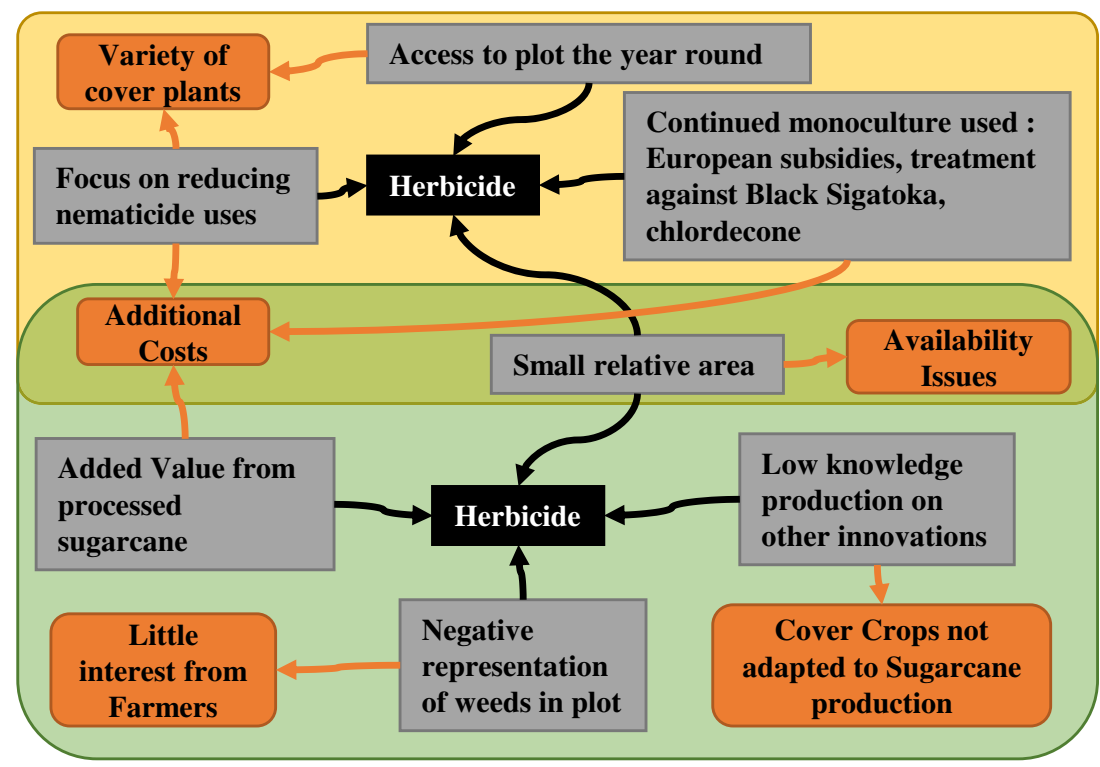


Gunby 1996; Wilson and Tisdell 2001) or has identified predictors of synthetic pesticide use in a region (Hammond Wagner et al. 2016). But few of them have combined a diagnosis at a territorial and supply chain scale to identify the technological and organisational brakes and levers to the sustainable transition of the territory. Organisation at the territorial scale is a key point that emerged from our analysis to manage herbicide pollution in the river. Indeed, pesticide transfers are strongly dependent on the heterogeneity of territories, meaning that they depend on where and when herbicides are applied. However, we showed that linking ecological processes to processes of social organisation (the different regimes of innovation in supply chain production) through the concept of socioecological system is very useful to understand the bottlenecks that blocked a collective management of the reduction of herbicide use in the territory.

This research allowed us to confirm our hypothesis, namely that the sustainable transition of a territory can be locked by a dominant herbicide use regime, maintained by the agricultural supply chains established on the territory. Indeed, our results showed that agricultural supply chains innovate but mainly in order to maintain their current farming system as much as possible, avoiding risk linked to change (here, mainly, the risk to reduce the production volumes of banana and sugarcane (global and per hectare)). As a result, each supply chain innovates independently one from each other, in a path defined and locked by the history of the supply chain and maintained today by rules, artefacts and networks of actors. This is the reason why service plants were innovations of interest for monocultural supply chains (such as banana or sugar cane), because they made it possible to maintain this monocultural system, taking little account of the constraints and resources of local territories. Some innovative farmers are trying to move away from the dominant regime model but have little technical support. This situation makes it difficult to reduce the herbicides globally used in the watershed.

However, our results also showed that, in parallel, local authorities want to reduce the presence of herbicides in the rivers. Nevertheless, the government authorities have given to the supply chains the responsibility of this reduction, which runs against the economic objectives of supply chains. Indeed, actors in the supply chains are mainly responsible for the economic survival of their farmers in their production area, prioritizing this aspect. Of course, the State keeps the right to remove the molecules as an ultimate lever to ensure that the supply chain actors will follow the objectives of the territory. But they do not propose any alternative solutions, because actors of the supply chains are asked to produce it. Finally, major supply chains keep state actors regularly aware of their difficulties in reducing pesticide uses and potential economic negative impacts, justifying the development of innovations that induce little change in their production systems.

In our case study, a programme of territorial development as a river contract could become a mean to coordinate the innovation of different sectors. This type of contract makes it possible to bring together actors who occupy different societal functions (agriculture, industries, etc.) in the same project, with the opportunity to build common objectives. It is now required that such programmes equip themselves with relevant tools to design and manage new organisation of activities on a territory to reduce pollution. Innovation platforms (Kilelu et al. 2013), companion modelling (Bousquet et al. 2010) and innovative design (Ravier et al. 2018) are such tools that our diagnosis, crossing a sociotechnical framework and a territorial framework, could feed to design new collective solutions to reduce pollution on a watershed scale.

Acknowledgements We are grateful to the farmers of the Galion River watershed and to the supervisors of the agricultural and environmental organisations we interviewed. We would like to say a special word of thanks to Landry Deffontaines for his helpful work.

Funding information The authors would like to thank the European Regional Development Fund (FEDER) and Agropolis Fondation for their financial support towards the RIVAGE (MQ0003772-CIRAD) and Stradiv projects. This action is also led by the French Ministry for Agriculture and Food and the French Ministry for an Ecological and Solidary Transition, with the financial support of the French Biodiversity Agency on "Resistance and Pesticides" research call, with the fees for diffuse pollution coming from the Ecophyto Plan.

\section{Compliance with ethical standards}

Conflict of interest The authors declare that they have no conflict of interest.

\section{References}

Bassereau D (1966) Mécanisation de la culture de la canne aux Antilles. L'Agronomie Tropicale. Série 1, Riz et Riziculture et Cultures Vivrières Tropicales, 21(10):1155-1161.

Belmin R, Casabianca F, Meynard J-M (2017) Contribution of the transition theory to the study of geographical indications. Environ Innov Soc Transit 27:32-47. https://doi.org/10.1016/j.eist.2017.10.002

Biarnès A, Bailly JS, Boissieux Y (2009) Identifying indicators of the spatial variation of agricultural practices by a tree partitioning method: the case of weed control practices in a vine growing catchment. Agric Syst 99:105-116. https://doi.org/10.1016/j.agsy.2008.10.002

Boiffin J, Benoît M, Le Bail M, Papy F, Stengel P (2014) Agronomie, espace, territoire : travailler « pour et sur » le développement territorial, un enjeu pour l'agronomie. Cah Agric 23:72-83. https://doi. org/10.1684/agr.2014.0688

Bonin M, Cathelin C (2014) Conversion environnementale de la production bananière guadeloupéenne : une stratégie politique et économique. Économie Rurale:63-82. https://doi.org/10.4000/ economierurale. 4329 
Bousquet F, Etienne M, d'Aquino P (2010) Introduction, in: La Modélisation d'accompagnement - Une Démarche Participative En Appui Au Développement Durable

Bugaud C, Fahrasmane L, Daribo MO, Aurore G, Chillet M, Fils-Lycaon B, Rinaldo D (2011) Exploration de la variabilité qualitative de la production bananière et des potentialités de transformation en vue d'une diversification. Innov Agron 16:13-23

Cholez C, Magrini M-B, Galliano D (2017) Les contrats de production en grandes cultures. Coordination et incitations par les coopératives. Économie Rurale:65-83. https://doi.org/10.4000/ economierurale. 5260

Clostre F, Letourmy P, Lesueur-Jannoyer M (2017) Soil thresholds and a decision tool to manage food safety of crops grown in chlordecone polluted soil in the French West Indies. Environ Pollut 223:357366. https://doi.org/10.1016/j.envpol.2017.01.032

Cowan R, Gunby P (1996) Sprayed to death: path dependance, lock-in and pest control strategies. Econ J 106:521-542. https://doi.org/10. 2307/2235561

Damour G, Dorel M, Quoc HT, Meynard C, Risède J-M (2014) A traitbased characterization of cover plants to assess their potential to provide a set of ecological services in banana cropping systems. Eur J Agron 52(part B):218-228. https://doi.org/10.1016/j.eja. 2013.09.004

David PA (1985) Clio and the economics of QWERTY. Am Econ Rev 75: 332-337

Della Rossa P, Jannoyer M, Mottes C, Plet J, Bazizi A, Arnaud L, Jestin A, Woignier T, Gaude J-M, Cattan P (2017) Linking current river pollution to historical pesticide use: insights for territorial management? Sci Total Environ 574:1232-1242. https://oi.org/10.1016/j. scitotenv.2016.07.065

Dolinska A, d'Aquino P (2016) Farmers as agents in innovation systems. Empowering farmers for innovation through communities of practice. Agric Syst 142:122-130. https://doi.org/10.1016/j.agsy.2015.11.009

Dubois A, Parisse S (2017) Pesticides: évolution des ventes, des usages et de la présence dans les cours d'eau depuis 2009. Ministère de l'Environnement, de l'Energie et de la Mer 4

Duke SO, Powles SB, Sammons R (2018) Glyphosate - how it became a once in a hundred year herbicide and its future. Outlooks Pest Manag 29:247-251

Duru M, Therond O, Fares M (2015) Designing agroecological transitions; a review. Agron Sustain Dev 35:1237-1257. https://doi.org/ 10.1007/s13593-015-0318-x

Emas R (2015) The concept of sustainable development: definition and defining principles. Brief GSDR 2015:3

Fares M, Magrini M-B, Triboulet P (2012) Agroecological transition, innovation and lock-in effects: the impact of the organizational design of supply chains. Cah Agric:34-45. https://doi.org/10.1684/agr. 2012.0539

Geels FW (2004) From sectoral systems of innovation to socio-technical systems. Res Policy 33:897-920. https://doi.org/10.1016/j.respol. 2004.01.015

Goulet F (2013) Narratives of experience and production of knowledge within farmers' groups. J Rural Stud 32:439-447. https://doi.org/10. 1016/j.jrurstud.2013.09.006

Hammond Wagner C, Cox M, Bazo Robles JL (2016) Pesticide lock-in in small scale Peruvian agriculture. Ecol Econ 129:72-81. https://doi. org/10.1016/j.ecolecon.2016.05.013

Harker KN, O'Donovan JT (2013) Recent weed control, weed management, and integrated weed management. Weed Technol 27:1-11. https://doi.org/10.1614/WT-D-12-00109.1

Ingram J (2018) Agricultural transition: niche and regime knowledge systems' boundary dynamics. Environ Innov Soc Transit 26:117135. https://doi.org/10.1016/j.eist.2017.05.001

Kilelu CW, Klerkx L, Leeuwis C (2013) Unravelling the role of innovation platforms in supporting co-evolution of innovation: contributions and tensions in a smallholder dairy development programme. Agric Syst 118:65-77. https://doi.org/10.1016/j.agsy. 2013.03.003

Labarthe P, Laurent C (2013) Privatization of agricultural extension services in the EU: towards a lack of adequate knowledge for smallscale farms? Food Policy 38:240-252. https://doi.org/10.1016/j. foodpol.2012.10.005

Laganier R, Villalba B, Zuindeau B (2002) Le développement durable face au territoire : éléments pour une recherche pluridisciplinaire. Dév Durable Territ. https://doi.org/10.4000/ developpementdurable.774

Lassoudière A (2012) Chapitre 8: recherhes participatives et pratiques de développement durable, depuis 1990, in: Le Bananiers, Un Siècle d'innovations Techniques. p 352

Lesueur Jannoyer M, Cattan P, Woignier T, Clostre F (eds) (2017) Crisis management of chronic pollution: contaminated soil and human health, urbanization, industrialization, and the environment. CRC Press, Boca Raton

Madelrieux S, Buclet N, Lescoat P, Moraine M (2017) Écologie et économie des interactions entre filières agricoles et territoire : quels concepts et cadre d'analyse ? Cah Agric 26:24001. https://doi.org/ $10.1051 /$ cagri/2017013

Mallessard R (1998) Pré-diagnostic de la filière de production banane de Guadeloupe. CIRAD-FLHOR

Markard J, Raven R, Truffer B (2012) Sustainability transitions: an emerging field of research and its prospects. Res Policy 41:955967. https://doi.org/10.1016/j.respol.2012.02.013

Maroušek J, Stehel V, Vochozka M, Kolář L, Maroušková A, Strunecký O, Peterka J, Kopecký M, Shreedhar S (2019) Ferrous sludge from water clarification: changes in waste management practices advisable. J Clean Prod 218:459-464. https://doi.org/10.1016/j.jclepro. 2019.02.037

Masiol M, Giannì B, Prete M (2018) Herbicides in river water across the northeastern Italy: occurrence and spatial patterns of glyphosate, aminomethylphosphonic acid, and glufosinate ammonium. Environ Sci Pollut Res 25:24368-24378. https://doi.org/10.1007/ s11356-018-2511-3

Maury C, Augusseau X, Aznar O, Bonin M, Bonnal P, Daré W, Décamps M, Jeanneaux P, Caron A (2013) Governance across multiple levels of Agri-environmental measures in France. In: Muradian R, Rival L (eds) Governing the provision of ecosystem services. Springer Netherlands, Dordrecht, pp 257-277. https://doi.org/10.1007/97894-007-5176-7 13

Mbolidi-Baron H (2002) Les conditions de durabilité de la production de la canne à sucre à la Martinique: une approche territoriale. Université de Toulouse-Le Mirail

Meiffren O, Oudin B, Gallois-Bride F, Galan M-B (2014) Evaluation du Plan Banane Durable 1 (No. Livrable 5). Ministères de l'Agriculture et des Outre-Mer

Meynard J-M, Charrier F, Fares M, Le Bail M, Magrini M-B, Charlier A, Messéan A (2018) Socio-technical lock-in hinders crop diversification in France. Agron Sustain Dev 38:1-13. https://doi.org/10.1007/ s13593-018-0535-1

Mottes C, Lesueur Jannoyer M, Le Bail M, Guéné M, Carles C, Malézieux E (2017) Relationships between past and present pesticide applications and pollution at a watershed outlet: the case of a horticultural catchment in Martinique, French West Indies. Chemosphere 184:762-773. https://doi.org/10.1016/j. chemosphere.2017.06.061

Mottes C, Deffontaines L, Charlier JB, Comte I, Della Rossa P, LesueurJannoyer M, Woignier T, Adele G, Tailame A-L, Arnaud L, Plet J, Rangon L, Bricquet J-P, Cattan P (2019) Spatio-temporal variability of water pollution by chlordecone at the watershed scale: what insights for the management of polluted territories? Environ Sci Pollut Res:1-15. https://doi.org/10.1007/s11356-019-06247-y 
Ravier C, Jeuffroy M-H, Gate P, Cohan J-P, Meynard J-M (2018) Combining user involvement with innovative design to develop a radical new method for managing $\mathrm{N}$ fertilization. Nutr $\mathrm{Cycl}$ Agroecosyst 110:117-134. https://doi.org/10.1007/s10705-0179891-5

Rodriguez GAP, Araujo Leon JA (2018) The glyphosate herbicide in Yucatan, Mexico. MOJ Bioequivalence Bioavailab. 5. https://doi. org/10.15406/mojbb.2018.05.00115

Schut M, Rodenburg J, Klerkx L, van Ast A, Bastiaans L (2014) Systems approaches to innovation in crop protection. A systematic literature review. Crop Prot 56:98-108. https://doi.org/ 10.1016/j.cropro.2013.11.017

Soulard CT (2005) Les agriculteurs et la pollution des eaux. Proposition d'une géographie des pratiques. Nat Sci Sociétés 13:154-164. https://doi.org/10.1051/nss:2005022

Sutherland L-A, Burton RJF, Ingram J, Blackstock K, Slee B, Gotts N (2012) Triggering change: towards a conceptualisation of major change processes in farm decision-making. J Environ Manag 104: 142-151. https://doi.org/10.1016/j.jenvman.2012.03.013

Vanloqueren G, Baret PV (2009) How agricultural research systems shape a technological regime that develops genetic engineering but locks out agroecological innovations. Res Policy 38:971-983. https://doi.org/10.1016/j.respol.2009.02.008

Wigboldus S, Klerkx L, Leeuwis C, Schut M, Muilerman S, Jochemsen H (2016) Systemic perspectives on scaling agricultural innovations. A review. Agron Sustain Dev 36:46-20. https://doi.org/10.1007/ s13593-016-0380-z

Wilson C, Tisdell C (2001) Why farmers continue to use pesticides despite environmental, health and sustainability costs. Ecol Econ 39: 449-462. https://doi.org/10.1016/S0921-8009(01)00238-5

Publisher's note Springer Nature remains neutral with regard to jurisdictional claims in published maps and institutional affiliations. 